\title{
Metabolit Sekunder Ekstrak Air Mendidih Daun Mangrove Sonneratia alba
}

\author{
Alfani Resky Dotulong ${ }^{1}$, Verly Dotulong ${ }^{1 *}$, Djuhria Wonggo ${ }^{1}$, Lita A.D.Y Montolalu ${ }^{1}$, \\ Silvana D. Harikedua ${ }^{1}$, Feny Mentang ${ }^{1}$, Lena J. Damongilala ${ }^{1}$ \\ 1Program Studi Teknologi Hasil Perikanan \\ Fakultas Perikanan dan Ilmu Kelautan, Universitas Sam Ratulangi. \\ Jl. Kampus Unsrat Bahu, Manado 95115, Sulawesi Utara, Indonesia. \\ *Penulis Korespondensi: verly_dotulong@unsrat.ac.id \\ (Diterima 17-05-2020; Direvisi 25-05-2020; Dipublikasi 27-05-2020)
}

\begin{abstract}
ABSTRAK
Daun mangrove Sonneratia alba secara tradisional sudah digunakan untuk mengobati berbagai macam penyakit yang disebabkan karena radikal bebas, hal ini mengindikasikan bahwa daun mangrove ini mengandung komponen metabolit sekunder yang dapat menghilangkan radikal bebas tersebut. Tujuan dari penelitian ini adalah mengidentifikasi komponen metabolit sekunder pada ekstrak air mendidih daun $S$. alba. Metode yang digunakan dalam penelitian ini bersifat eksploratif yaitu mendapatkan data secara kualitatif yaitu ada tidaknya senyawa fenolik, flavonoid, saponin, triterpenoid, tannin dan alkaloid dalam ekstrak air mendidih daun $S$. alba yang dikeringkan di bawah sinar matahari (KSM) dan dianginanginkan di dalam ruangan (KDR) selama 40, 50 dan 60 menit. Hasil penelitian yang diperoleh adalah sebagai berikut: ekstrak air mendidih selama 40 menit baik untuk cara pengeringan KSM maupun KDR mengandung semua komponen metabolit sekunder yang diuji yaitu fenolik, flavonoid, tannin, saponin, triterpenoid dan alkaloid, sedangkan untuk ekstrak dengan lama ekstraksi 50 dan 60 menit tidak mengandung flavonoid dan saponin.
\end{abstract}

Kata kunci: Daun, Sonneratia alba, ekstra, metabolit sekunder.

\section{PENDAHULUAN}

Mangrove adalah salah satu tumbuhan pesisir pantai yang berpotensi sebagai sumber antioksidan karena mengandung metabolit sekunder dimana Indonesia merupakan negara yang mempunyai luas hutan mangrove dengan keragaman hayati terbesar dan mempunyai struktur paling bervariai (Noor et. al.,1999), termasuk didalamnya daerah Sulawesi Utara. Jenis mangrove yang dominan di Sulawesi Utara yaitu Rhizopora, Bruguera dan Soneratia (Kaunang dan Kimbal, 2009). Sonneratia alba adalah spesies mangrove yang dominan di Desa Wori, Kecamatan Wori, Kabupaten Minahasa Utara, Provinsi Sulawesi Utara (Karaowan, 2011).

Daun mangrove yang muda biasa dikonsumsi sebagai sayuran, pengambilan daun muda ini tidak merusak tumbuhan mangrove karena bila pucuk dipetik maka akan tumbuh tunas baru sehingga daun mangrove semakin rimbun. Daun mangrove dewasa ini masih kurang diteliti kandungan metabolit sekundernya, padahal secara tradisional seluruh bagian tumbuhan mangrove sudah digunakan untuk mengobati berbagai macam penyakit yang disebabkan karena radikal bebas (Bandarayanake, 1998), hal ini mengindikasikan bahwa tumbuhan mangrove termasuk daunnya mengandung metabolit sekunder penting untuk kesehatan, sehingga ke depan dapat dikembangkan sebagai minuman (teh) fungsional.

Penelitian tentang kandungan fitokimia mangrove $S$. alba dari pesisir Desa Wori antara lain: Wonggo et. al. (2017) tentang ekstrak metanol buah S. alba menghasilkan senyawa kimia yang teridentifikasi adalah flavonoid, fenolik, tannin. Dotulong et. al. (2018a) melaporkan bahwa ekstrak daun mangrove $S$. alba dengan air mendidih selama 10, 20 dan 30 menit mengandung metabolit sekunder.

fenolik, flavonoid, saponin, triterpenoid, tanin dan alkaloid dan tidak mengandung steroid. Berdasarkan hal ini maka penelitian yang akan dilakukan adalah mengekstrak metabolit sekunder dari daun $S$. alba menggunakan ekstraksi dengan air mendidih pada daun mangrove yang dikeringkan di bawah sinar matahari dan dikeringkan di dalam ruangan, dengan lama waktu ekstraksi yang lebih lama yaitu 40, 50 dan 60 menit untuk mendapatkan data tentang jenis 
metabolit sekunder yaitu fenolik, flavonoid, tannin, saponin, triterpenoid dan alkaloid, sehingga kedepan dapat dikembangkan sebagai teh fungsional.

Selain itu kegiatan ini adalah suatu penelitian yang inovatif dengan menggali potensi daerah yaitu daun $S$. alba yang dominan tumbuh di pesisir Desa Wori, Kecamatan Wori, Kabupaten Minahasa Utara, Provinsi Sulawesi Utara sebagai teh fungsional antioksidan tahan suhu tinggi.

\section{METODE PENELITIAN}

\section{Bahan dan Alat}

Bahan baku yang digunakan dalam penelitian ini adalah daun muda $S$. alba 3-4 helai dari pucuk, diambil di pesisir Desa Wori, Kecamatan Wori, Kabupaten Minahasa Utara, Provinsi Sulawesi Utara. Daun ini telah diidentifikasi di Herbarium Jatinangor, Laboratorium Taksonomi Tumbuhan, Departemen Biologi FMIPA UNPAD Bandung. Bahan-bahan kimia yang digunakan dalam penelitian ini diperoleh dari Merck. Co.Ltd dan Sigma Aldrich Co. Ltd (St. Louis, MO, USA) yaitu sekelompok reagen. Untuk uji fitokimia yaitu dari produk Merck $\left(\mathrm{FeCl}_{3}, \mathrm{HCl}, \mathrm{Mg}\right.$, $\mathrm{H}_{2} \mathrm{SO}_{4}, \mathrm{NaOH}, \mathrm{CH}_{3} \mathrm{COOH}$ anhidrid, Pereaksi Dragendorff dan Pereaksi Wagner.

Alat-alat yang digunakan dalam penelitian ini antara lain kompor gas, wadah alumunium untuk ekstraksi dengan air mendidih, oven merek Eyela NDO-410, untuk pengeringan sampel, spektrofotometer dan seperangkat alas gelas.

\section{Tata Laksana Penelitian}

a. Metode pembuatan ekstrak air mendidih daun S. alba didahului dengan menyiapkan daun mangrove yang sudah dibersihkan selanjutnya dikeringkan dengan dua cara yaitu: 1 . diangin-anginkan di dalam ruangan; 2. dikeringkan di bawah sinar matahari, sampel tersebut disebut simplisia.

b. Simplisia kemudian diblender sehingga dihasilkan serbuk. Simplisia yang telah dihaluskan sebanyak $50 \mathrm{~g}$ dimasukan ke dalam 3 liter air mendidih (suhu $96-98^{\circ} \mathrm{C}$ ) dalam wadah stainless steel di atas kompor dan diekstrak dengan cara merendam/merebus bubuk mangrove tersebut selama 40, 50, dan 60 menit. Selanjutnya dilakukan penyaringan dengan kertas saring whatman no. 1 untuk memisahkan ekstrak encer dari serbuk daun mangrove.

c. Ekstrak encer dipekatkan dengan cara menguapkan ekstrak tersebut dalam wadah stainless steel di atas kompor dengan suhu $90^{\circ} \mathrm{C}$ hingga dihasilkan ekstrak kental, ekstrak kental selanjutnya dimasukkan dalam botol-botol kecil berwarna gelap dan dikeringkan dalam oven pada suhu $60^{\circ} \mathrm{C}$ sampai semua pelarut air teruapkan.

d. Eksrak tersebut selanjutnya dianalisa kandungan metabolit sekunder (fitokimia) yaitu senyawa fenolik, flavonoid, saponin, triterpenoid, tannin dan alkaloid mengikuti prosedur dalam Harborne (2006).

\section{Perlakuan dalam Penelitian}

Cara Pengeringan Sampel terdiri atas 2 perlakuan yaitu: pengeringan sinar matahari (KSM) dan pengeringan dengan cara diangin-anginkan di dalam ruangan (KDR), serta lama waktu ekstraksi dalam air mendidih, terdiri dari 3 perlakuan, yaitu: 40, 50 dan 60 menit.

\section{Analisa Data} bentuk tabel.

Penelitian ini bersifat eksploratif, data dianalisis secara deskriptif dan data disajikan dalam

\section{HASIL DAN PEMBAHASAN}

Kandungan metabolit sekunder (fitokimia) ekstrak air mendidih dari daun mangrove S. alba yang dikeringkan dengan sinar matahari dan yang dikeringkan dengan cara diangin-anginkan di dalam ruangan dengan lama waktu ekstraksi 40, 50 dan 60 menit dapat dilihat pada Tabel 1.

Data pada Tabel 1 memperlihatkan bahwa ekstrak air mendidih daun $S$. alba baik yang dikeringkan di bawah sinar matahari maupun yang dikeringkan dengan cara diangin-anginkan di dalam ruangan mengandung semua komponen metabolit sekunder (fitokimia) yang diuji, kecuali untuk lama ekstraksi 50 dan 60 menit untuk dua metode pengeringan tidak mengandung flavonoid dan saponin. Hal ini kemungkinan disebabkan kedua komponen kimia ini tidak tahan panas 
sehingga bila dipanaskan pada suhu air mendidih lebih lama maka senyawa tersebut mengalami kerusakan.

Tabel 1. Metabolit Sekunder Ekstrak Air Mendidih Daun Mangrove Sonneratia alba.

\begin{tabular}{|c|c|c|c|c|c|c|c|c|}
\hline \multirow{3}{*}{ No } & \multirow{3}{*}{$\begin{array}{l}\text { Metabolit } \\
\text { Sekunder }\end{array}$} & \multirow{3}{*}{ Metode Uji } & \multicolumn{6}{|c|}{ Hasil Uji Lama Ekstraksi } \\
\hline & & & \multicolumn{2}{|c|}{40 Menit } & \multicolumn{2}{|c|}{50 Menit } & \multicolumn{2}{|c|}{60 Menit } \\
\hline & & & KSM & KDR & KSM & KDR & KSM & KDR \\
\hline 1 & Fenolik & Pereaksi FeCl3 5\% & + & + & + & + & + & + \\
\hline 2 & Tanin & Pereaksi $\mathrm{FeCl}_{3} 1 \%$ & + & + & + & + & + & + \\
\hline \multirow[t]{3}{*}{3} & Flavonoid & a. Pereaksi $\mathrm{HCl}$ pekat $+\mathrm{Mg}$ & + & + & - & - & - & - \\
\hline & & b. Pereaksi $\mathrm{H}_{2} \mathrm{SO}_{4} 2 \mathrm{~N}$ & + & + & - & - & - & - \\
\hline & & c. Pereaksi $\mathrm{NaOH} 10 \%$ & + & + & + & + & + & + \\
\hline 4 & Saponin & Pereaksi $\mathrm{HCl} 2 \mathrm{~N}$ & + & + & - & - & - & - \\
\hline 5 & Triterpenoid & Pereksi $\mathrm{H}_{2} \mathrm{SO}_{4}$ pekat $+\mathrm{CH} 3 \mathrm{COOH}$ anhidrid & + & + & + & + & + & + \\
\hline \multirow[t]{2}{*}{6} & Alkaloid & a. Pereaksi Dragendorff & + & + & + & + & + & + \\
\hline & & b. Pereaksi Wagner & + & + & + & + & + & + \\
\hline
\end{tabular}

Data kandungan metabolit sekunder (fitokimia) pada Tabel 1 ini menunjukkan bahwa ekstrak air mendidih dari daun muda $S$. alba kaya akan metabolit sekunder yang berfungsi sebagai antioksidan yaitu positif mengandung senyawa fenolik, flavonoid, saponin, triterpenoid, tanin dan alkaloid. Hal ini didukung oleh hasil penelitian Dotulong et. al. (2018b) yang melaporkan bahwa kandungan senyawa fitokimia pada ekstrak metanol dan etanol daun muda $S$. alba mengandung senyawa fitokimia yaitu fenol, flavonoid, steroid, Triterpenoid, saponin, tanin dan alkaloid, dimana komponen-komponen kimia ini menyebabkan daun mangrove mempunyai aktivitas antioksidan yang tergolong kuat. Das et. al., (2014) melaporkan bahwa ekstrak air dari mangrove Xylocarpus granatum tidak mengandung komponen fitokimia. Komponen fitokimia pada ekstrak daun muda $S$. alba ini lebih banyak jenisnya dibandingkan dengan hasil penelitian Wonggo et. al., (2017) pada buah $S$. alba muda yang diambil pada lokasi yang sama hanya mengandung fenolik, flavonoid dan tanin.

Senyawa-senyawa metabolit sekunder (fitokimia) ini mempunyai fungsi biologis tertentu pada tumbuhan. Senyawa fenolat yang terdapat pada tumbuhan mangrove dapat melindungi tumbuhan ini dari kerusakan akibat radiasi ultraviolet (Agatietal, 2007). Hal ini didukung oleh pernyataan Banerjee et. al. (2008), bahwa kecenderungan peningkatan produksi senyawa fenolat pada tumbuhan mangrove terjadi bila mangrove tersebut tumbuh dan bertahan dalam kondisi tertekan.

Flavonoid pada tanaman bertindak sebagai pelindung terhadap tekanan yang berasal dari lingkungan (Percival, 1998). Pada tanaman, triterpenoid berfungsi sebagai anti mikroba (Riyanto et. al., 2013).

\section{KESIMPULAN}

Ekstrak air mendidih daun mangrove Sonneratia alba baik yang dikeringkan di bawah sinar matahari maupun yang dikeringkan dengan cara diangin-anginkan di dalam ruangan selama 40 menit mengandung komponen metabolit sekunder (fitokimia) yaitu fenolik, flavonoid, triterpenoid, saponin, tanin dan alkaloid. Ekstrak dengan lama ekstraksi 50 dan 60 menit untuk dua metode pengeringan daun mangrove Sonneratia alba tidak mengandung flavonoid dan saponin.

Perlu dilakukan penelitian lebih lanjut tentang berapa besar kandungan metabolit sekunder komponen fitokimia yang terkandung didalam ekstrak air mendidih daun mangrove Sonneratia alba.

\section{DAFTAR PUSTAKA}

Agati,G., Matteinni, P., Goti, A. \& Tattini, M. (2007). Chloroplast located Ca Scavenge Singlet Oxygen. New Phytologist. 174: 77-82.

Bandaranayake, W. M. (2002). Bioactivities, Bioactive Compounds \& Chemal Constituents of Mangrove Plants. Wetlands Ecol. Manage. 10: 421-452.

Banerjee, D., Chakrabarti,S.,Hazra, A.K.,Banerjee, S., Ray, J., and Mukherjee, B. (2008). Antioxidant Activity \& Total Phenolics of Some Mangroves in Sundarbans. African Journal of Biotechnology. 7(6): 805. 
Das, S. K., Samantaray,D., and Thatoi, H. (2014). Mangrove Plants of The Genus (Xylocarpus): A Mini Review. J. Bional Biomed. 12.

Dotulong V, Wonggo D and Montolalu L.A.D.Y. (2018)a. Potensi Antioksidan Daun Muda Mangrove (Sonnerratia alba) Sebagai Minuman Fungsional. Laporan Akhir Riset Terapan Unggulan Unsrat. Universitas Sam Ratulangi Manado. 29 Halaman.

Dotulong V., Wonggo D., Montolalu L.A.D.Y. (2018)b. Phytochemical Content, Total Phenols, \& Antioxidant Activity of Mangrove (Sonneratia alba) Young Leaf Through Different Extraction Methods \& Solvents. International Journal of ChemTech Research. Vol.11 No.11, pp 356-363.

Harbone, J.B. (2006). Metode Fitokimia. Penuntun Cara Modern Menganalisis Tumbuhan. Terbitan II. Diterjemahkan oleh Kosasih Padmawinata \& Iwang Soediro. Penyunting Sofia Mansoor. ITB. Bandung.

Kaunang D.T dan Kimbal J.D. (2009). Komposisi \& Struktur Vegetasi Hutan Mangrove di Taman Nasional Bunaken Sulawesi Utara. Agritek Vol. 17 No. 5 November (2009). ISSN 0852-5426. Hal: 1163-1171.

Karauwan, M.A. (2011). Kondisi Ekosistem Mangrove di Kecamatan Bunaken Sulawesi Utara. J. Pariwisata.

Noor, Y.R., M. Khazali, I.N.N Suryaputra. (1999). Panduan Pengenalan Mangrove di Indonesia. PKA/WI-IP. Bogor.

Percival, M. (1998). Antioxidants. Clinical Nutrition Insights. 31(10): 1-4.

Ryanto, E.L., Widowati, I, \& Sabdono , A. (2013). Skrining Aktivitas Antibakteri pada Ekstrak (Sargasum polycytum) terhadap bakteri vibrio harveyi \& Micrococcus luteus di Pulau Panjang Jepara. Journal of Marine Research 1(1): $115-121$.

Wonggo D, Berhimpon S, Kurnia D. \& Dotulong V. (2017). Antioxidant Activities of Mangrove Fruit (Sonneratia alba) taken from Wori Village, North Sulawesi, Indonesia. International Journal of ChemTech Research. Vol.10 No.12: 284-290. 